\title{
METHOD OF DEVELOPING COMPANY'S ORGANIZATIONAL PROFILE
}

\author{
V. Milusheva* \\ Department of Industrial Business, UNWE - Sofia, Bulgaria
}

\begin{abstract}
Organizational design is a field that is being increasingly recognized by both managers and scholars. It has undoubtedly been the subject of numerous theoretical papers. The same however cannot be said about the practical application of the proposed theoretical approaches aimed to establish the organizational level of companies and its improvement.

The purpose of this article is to present an approach and methodological bases capable of establishing companies' organizational level by developing the so called "organizational profiles". The proposed approach is based on a quantitative assessment method using organizational parameters shown to be significant. These are used as grounds for identifying "problematic areas" and possibilities to overcome such areas. The organizational profile also demonstrates the extent to which the company management has chosen the appropriate strategy for organizing its processes and operations in terms of functions.

The results from applying the method for developing company's organizational profile are related to the improvement in the organization of the ongoing processes in the company as a whole. This method can be used in the day-to-day operations of business organizations in their pursuit of an improved organizational level.
\end{abstract}

Key words: company, company organization, organizational design, method, analysis

\section{INTRODUCTION}

Compaines' organizational condition has a strong impact on the processes taking places in them and their operations which affects the end results of their business. In today's dynamically changing external environment, company organization needs an expert study of its actual level, and in particular of expert study of its compliance with changes. The method presented in the article has been adapted based on the reasoning adopted in the development of motivational profiles for organization's human resources developed by Prof. Yosif Iliev (1).

The purpose of the article is to present a method for developing company a company's organizational profile which may aid the management of business organizations.

The article puts forward the following proposition: In line with the scientific

\footnotetext{
*Correspondence to: Vyara Milusheva, Department of Industrial Business, UNWE - Sofia, Bulgaria, 53 Radko Dimitriev St, Plovdiv, BULGARIA, vyara_milusheva@yahoo.com,0899607093
}

stipulations about company's organization and organization design, it is possible to substantiate and incorporate in a methodical plan basic organization design parameters, to make an expert assessment of their conditions and to derive, in practical aspect, the actual organizational profile of a company.

\section{Company's organizational profile - methodological issues}

In today's dynamic business environment, the effect of multiple internal and external factors gives rise to an objective need to make organizational changes in companies. Improvement in the existing company organization has a crucial impact on companies' competitiveness. In that regard it can be said that company organization and in particular the high-level of organization design of processes and operations has the potential of being a competitive advantage of companies.

The two key terms in this article are: organization of a company; organization design of a company. The connection and correlation between the two is undeniable. In 
summary - the organization design of a company is the result of the previously conducted process of its organization.

\section{Overview of organization of a company}

From a scientific point of view, the organization of a company comprises two mutually related aspects:

Organization as a management function of building and/or improving company's organizational structure. In that aspect, the emphasis is on creating preconditions and environment to achieve the strategic and operational goals of the company, including hierarchical arrangement in management levels, units and positions; authorities and responsibilities; interactions and relations, etc., for the successful management of the entire company business;

Organization as production function (2) is related to building and/or improving company's production structure. In that aspect, the emphasis is on creating preconditions and environment to successfully (effectively) conduct the production processes in the company. In that regard, preconditions and environment are directly manifested in the sound combination in space and time of the range of components of the production structure into a single organism in a way which allows the company to continue to operate in an efficient manner.

The above two aspects of the organization of a company provide an argument to note the following: Regardless of their relative independence, they should be viewed as connected and correlated. This requirement is satisfied by the unified application of two approaches:

structural approach which is realized by breaking down (taking apart, respectively) company processes, creating relatively independent constituents and forming adequate units for their implementation; Modern scientific stipulations and recommendations point that these units, regardless of their place in the company, should be built and developed on the principles of team work and progress towards formation of efficient teams;

systemic approach aimed to establish connections, correlations and interaction among company's structural elements (units). The application of the systemic approach "starts off" by assuming units' independence but puts their dependencies and mutual influence to the fore and this, in essence, makes a company a functioning organism.

\section{Overview of organization design of a} company

Company's organization design (3-4) is the result of the conducted process and scope of activities on its organization. It can definitely be said that organization design is a relatively static category. At the same time, as a result of the effect of numerous factors (internal and external to the company), the actual condition (or level) of company's organization design must be modified. When an expert assessment of a company's organization design provides evidence of the existence of "problematic areas", these areas must be resolved through appropriate project decisions within the organizational scope.

Company's organization design, as a factual state, can be successfully diagnosed (5). Diagnostics reveal problematic and good practices in company's organization design and reference objectives towards overcoming problematic practices.

Organization is the process which defines the level of company's organization design. The identification of deficiencies in companies' organization design and subsequently using it as a basis for overcoming such deficiencies requires an approach which allows for comprehensive assessment of the condition (level) of company's organization design.

\section{Methodological issues when developing company's organization profile}

The main objective of the approach proposed in the article is to pursue the following through its routine application in the day-to-day operations of companies:

to determine the true (real) level of company's organization design;

- to reveal (identify) limiting factors and reasons which have created conditions for inadequate organization design of companies' processes - the problematic areas in the organization design, respectively;

to propose and implement project decisions to handle problematic areas and to increase companies organization design level.

The methodological issues when developing organizational profiles of companies are influenced by an article by Professor Yosif Iliev (1). The article adopts the following concept of organizational profile: Organizational profile is (characterizes, respectively) the level of the actual organization design of a company established (or regularly established) through an adequate 
range of factors which define it, organizational parameters, respectively.

The above concept produces the following two key questions warranting an answer:

First, to carry out a reasoned selection of the factors which define the condition of a company's organization design. These factors are further defined as organizational parameters;

Second, to propose a suitable method for sufficiently accurate expert assessment of the condition of each organizational parameter. In terms of substantiating the organizational parameters, the following aspects can be summarized:

Company organization (6) covers a wide range of sets and subsets aligned with the processes and activities in companies. The diversity of processes and activities in the classical organization science is divided in two parts production organization; labor organization. On the surface, this characterizes the organization of the production function in companies. At the same time, its management function and its orientation towards the organizational and management structure of companies in line with the production structure lie at the heart of a wholesome and fully fledged company organization.

The aforementioned two aspects provide an argument to define organizational parameters which characterize the organizational level of companies.

Below (Table 1) is a proposed range of twenty organizational parameters covering to a sufficient degree the various aspects of company's organization design as well as a grading scale for assessing the condition of organizational parameters, the article proposes a simplified three-grade scale, namely:

first grade: Characterizes the optimal condition of an organizational parameter;

second grade: Characterizes the satisfactory condition of an organizational parameter;

third grade: Characterizes the unsatisfactory condition of an organizational parameter;

Organizational parameters and the grading scale for their condition are presented in Table $\mathbf{1}$ which can be defined as a base questionnaire form.

Other grading scales for assessing the condition of organizational parameters are also possible, such as:

The following important questions are clarified upon providing the base questionnaire and briefing the participating managers on its completion:

Necessity to carefully review the organization design parameters of (in) the company included in column 2 of the form. At respondent's discretion, he/she may, for example, add one or two new parameters, if they have not been included in the form but the respondent considers them important. Expertly and based on their views, the respondent may compile their own „ranking” of the top ten most important parameters of company's organization design. Their ranking from 1 to 10 is to be listed in column 3 of the form.

Respondents must pay particular attention when filling columns 4,5 or 6 of the base form. In this case this is a matter of the individual respondent's expert assessment of the actual condition of the company's organizational parameters - of each one separately. From the point of view of the individual respondent, problematic parameters of the company's organization design are present in column 5 and especially in column 6. The individual (personal) orientation of the base questionnaire form towards the participants in the survey is one of the two approaches to developing company's organizational profile. Second, also an appropriate approach, is represented through the "collective" completion of the base questionnaire. This approach employs the following "workflow":

each representative of the management staff and each participant in the survey receives beforehand the methodical guidance and form their opinion on the "ranking" and assessment of the condition of the organizational parameters;

- in a joint discussion of the survey participants, they reach a common (unified) "ranking" of the top ten most important organizational parameters for the company and a common (unified) assessment of their actual condition in the company.

Where respondents are also representatives of the company's management staff, they are not required to "disclose" themselves through their distinctive features. The argument here is that the mangers have competences, understanding of and are knowledgeable about the organizational parameters.

Processing of the individual questionnaires and summarizing survey results. 
MILUSHEVA V.

Table 1. Base questionnaire form

\begin{tabular}{|c|c|c|c|c|c|}
\hline \multirow[t]{2}{*}{ No. } & \multirow[t]{2}{*}{ Organizational parameters (organization factors) } & \multirow{2}{*}{$\begin{array}{l}\text { ranking list } \\
\text { of the } 10 \text { most } \\
\text { important } \\
\text { parameters }\end{array}$} & \multicolumn{3}{|l|}{ Grading scale } \\
\hline & & & $\begin{array}{l}\text { optimal } \\
\text { condition of } \\
\text { the parameter }\end{array}$ & $\begin{array}{l}\text { satisfactory } \\
\text { condition of } \\
\text { the parameter }\end{array}$ & $\begin{array}{l}\text { Unsatisfacto } \\
\text { ry condition } \\
\text { of the } \\
\text { parameter }\end{array}$ \\
\hline 1 & 2 & 3 & 4 & 5 & 6 \\
\hline 1 & $\begin{array}{l}\text { Condition (level, respectively) of company's management } \\
\text { organizational structure. }\end{array}$ & & & & \\
\hline 2 & $\begin{array}{l}\text { Condition (level, scale, respectively) of company's } \\
\text { production structure. }\end{array}$ & & & & \\
\hline 3 & $\begin{array}{l}\text { Condition of the spatial arrangement of the production } \\
\text { process in the company }\end{array}$ & & & & \\
\hline 4 & $\begin{array}{l}\text { Condition of the temporal arrangement of the production } \\
\text { process in the company (its course over time, respectively). }\end{array}$ & & & & \\
\hline 5 & $\begin{array}{l}\text { Condition of the auxiliary processes in the company (repairs; } \\
\text { transport; warehousing) in terms of normal maintenance of } \\
\text { the main production process. }\end{array}$ & & & & \\
\hline 6 & $\begin{array}{l}\text { Condition (level of completeness and organization design, } \\
\text { respectively) of the teams within the company's management } \\
\text { organizational structure. }\end{array}$ & & & & \\
\hline 7 & $\begin{array}{l}\text { Condition (level of completeness and organization design, } \\
\text { respectively) of the teams within the company's production } \\
\text { structure. }\end{array}$ & & & & \\
\hline 8 & $\begin{array}{l}\text { Available resources for company operation (long- and short- } \\
\text { term assets, respectively - assets' condition). }\end{array}$ & & & & \\
\hline 9 & $\begin{array}{l}\text { Available human resources for company operations } \\
\text { (streamlined or non-streamlined size and structure of human } \\
\text { resources; level of qualification (competence) versus position } \\
\text { requirements). }\end{array}$ & & & & \\
\hline 10 & $\begin{array}{l}\text { Condition (level, scale) of work motivation of company's } \\
\text { human resources (staff engagement in the company goals, } \\
\text { respectively; work satisfaction; durable sentiment among } \\
\text { personnel that they are being treated fairly by their } \\
\text { supervisors, etc). }\end{array}$ & & & & \\
\hline 11 & $\begin{array}{l}\text { Human resources qualification approach adopted by the } \\
\text { company } \\
\text { 1). Depthwise qualification; } \\
\text { 2) Widthwise qualification, respectively) and any resultant } \\
\text { effects on the work. }\end{array}$ & & & & \\
\hline 12 & $\begin{array}{l}\text { Condition (level, scale, respectively) of team organization of } \\
\text { labor in the company (adherence to the major principles of } \\
\text { team setup, respectively; team coherence achieved; efficiency } \\
\text { of company teams). }\end{array}$ & & & & \\
\hline 13 & $\begin{array}{l}\text { Management's approach and routine with respect to relations } \\
\text { and interactions between "supervisors - supervised" (ensured } \\
\text { awareness among the staff about company's strategy and } \\
\text { goals, respectively; room for initiatives for improvement; } \\
\text { ensured upward trend over time in the relative share of } \\
\text { employees, carriers of human capital). }\end{array}$ & & & & \\
\hline 14 & $\begin{array}{l}\text { Condition of piecework system in the company (adherence to } \\
\text { basic principles when developing piecework system, } \\
\text { respectively; piecework system ensures full utilization of } \\
\text { human resource potential; piecework systems provides for } \\
\text { adequate motivational effects). }\end{array}$ & & & & \\
\hline 15 & $\begin{array}{l}\text { Condition of work environment in the company (compliance } \\
\text { / non-compliance of the work conditions in the company with } \\
\text { Bulgarian and European standards for optimal work } \\
\text { environment, respectively). }\end{array}$ & & & & \\
\hline 16 & $\begin{array}{l}\text { Alignment between the company's actual organization design } \\
\text { and its business strategy. }\end{array}$ & & & & \\
\hline 17 & $\begin{array}{l}\text { Condition of company and organizational culture of the } \\
\text { human resources in the company. }\end{array}$ & & & & \\
\hline 18 & $\begin{array}{l}\text { Organizational initiatives for improvement by company staff } \\
\text { members. }\end{array}$ & & & & \\
\hline 19 & $\begin{array}{l}\text { Established synergy between the units of the company's } \\
\text { management organizational structure and its production units. }\end{array}$ & & & & \\
\hline 20 & Ensured competitive advantage of company's organization & & & & \\
\hline
\end{tabular}


Surveyed individuals (managers) have completed their expert assessment. Questionnaires are processed in a specific sequence and in accordance with specific rules: a) determining the "ranking of top ten most important organizational parameters" for the surveyed sample of managers (sample of students, respectively) :

- all separate questionnaires are processed (summarized) for the contents of column 3 of the initial questionnaire;

- the summarized ranking of the top ten most important organizational parameters for the sample is determined in accordance with the following formula:

Relative weight $=(\mathrm{m} 1 . \mathrm{A}+\mathrm{m} 2 . \mathrm{B}+$ ...........m n. Z $):(\mathrm{m} 1+\mathrm{m} 2+\ldots \mathrm{mn})$,

where: $(\mathrm{m} 1+\mathrm{m} 2 \ldots \ldots+\mathrm{mn})$ is the number of surveyed individuals;

A, B, C, ....Z., - the place of the organizational parameter in the rankings compiled by the surveyed respondent.

The following rule is employed for the ranking of organizational parameters: The smaller the value (relative weight) of the parameter, the more important and further up the importance ranking the respective organization design parameter is, or: the ranking of the top ten most important parameters will start with the parameter with the lowest relative weight and in ascending order of the weights will end with the tenth parameter.

b) summarizing the relative share (percentage) of the surveyed individuals who have confirmed "yes" for each parameter in columns 4 or 5 , or 6 of the separate questionnaires.

Table 2 presents a working form provisionally filled with ten important organizational parameters as a ranking of parameters important for the general condition of company organization. The expert assessment produced through actual participation of respondents managers will reflect their take on the ranking at the particular company. The percentages in columns 3,4 and 5 of the form indicate the relative share of the surveyed individuals (their total is $100 \%$ ) who have assigned the respective score level to the organizational parameters. In the sample table No. Summarized form of organizational parameters the above relatives shares have not been filled in.

Table 2. Summarized form of organizational parameters

\begin{tabular}{|c|c|c|c|c|}
\hline \multirow[t]{2}{*}{ No. } & \multirow[t]{2}{*}{ Sample ranking of organizational parameters } & \multicolumn{3}{|c|}{ Summarized survey results } \\
\hline & & $\begin{array}{l}\text { Optimal } \\
\text { condition } \%\end{array}$ & $\begin{array}{l}\text { Satisfactory } \\
\%\end{array}$ & $\begin{array}{l}\text { Unsatisfacto } \\
\text { ry } \%\end{array}$ \\
\hline 1 & 2 & 3 & 4 & 5 \\
\hline 1 & $\begin{array}{l}\text { Condition (level, respectively) of company's management organizational } \\
\text { structure. }\end{array}$ & E.g. $60 \%$ & E.g. $30 \%$ & E.g. $10 \%$ \\
\hline 2 & $\begin{array}{l}\text { Condition of the temporal arrangement of the production process in the } \\
\text { company (its course over time, respectively). }\end{array}$ & & & \\
\hline 3 & $\begin{array}{l}\text { Condition (level of completeness and organization design, respectively) of } \\
\text { the teams within the company's production structure }\end{array}$ & & & \\
\hline 4 & $\begin{array}{l}\text { Available human resources for company operation (streamlined or non- } \\
\text { streamlined size and structure of human resources; level of qualification } \\
\text { (competence) versus job requirements). }\end{array}$ & & & \\
\hline 5 & $\begin{array}{l}\text { Human resources qualification approach adopted by the company ( } \\
\text { 1) depthwise qualification; } \\
\text { 2) widthwise qualification) and any resultant effects on the work. }\end{array}$ & & & \\
\hline 6 & $\begin{array}{l}\text { Management's approach and routine with respect to relations and interactions } \\
\text { between "supervisors - supervised" (providing awareness among the staff } \\
\text { about company's strategy and goals, respectively; providing room for } \\
\text { initiatives for improvement; ensuring upward trend over time in the relative } \\
\text { share of employees, carriers of human capital) }\end{array}$ & & & \\
\hline 7 & $\begin{array}{l}\text { Condition of piecework system in the company (adherence to basic } \\
\text { principles when developing piecework system, respectively; piecework } \\
\text { system ensures full utilization of human resource potential; piecework } \\
\text { systems provides for adequate motivational effects). }\end{array}$ & & & \\
\hline 8 & $\begin{array}{l}\text { Condition of work environment in the company (compliance / non- } \\
\text { compliance of the work conditions in the company with Bulgarian and } \\
\text { European standards for optimal work environment, respectively). }\end{array}$ & & & \\
\hline 9 & $\begin{array}{l}\text { Condition of company and organizational culture of the human resources in } \\
\text { the company. }\end{array}$ & & & \\
\hline 10 & $\begin{array}{l}\text { Established synergy between the units of the company's management } \\
\text { organizational structure and its production units }\end{array}$ & & & \\
\hline
\end{tabular}




\section{Guidance for analyzing company's} organizational profile

The organizational profile is, above all, a device, a tool, in the hands of the managers (management) of the company for developing and implementing management actions and measures resultant of such a profile which are aimed at improving company's organization design. Creative aspects are present in the analysis and assessment of the organizational profile and in the consequent management actions in accordance with the conclusions from the analysis and assessment.

The following is an important preliminary consideration. The effects from developing companies' organizational profiles occur when:

profiles have been developed in various company cross-sections - on a company-wide scale and on a company division level, profiles are being developed on an ongoing, regular basis.

Adopting such an approach towards defining organizational profiles increases the possibilities for an in-dept analysis of a company's organizational level. This allows for opportunities to conduct a comparative analysis of the various profiles and to evaluate the positive changes in the organization design over time.

On the analysis of a separate organizational profile:

The "ten most important organizational parameters" of the company have been summarized.

This preliminary "step" of the analysis is useful for the senior management due to it's quality of being a common position of the managers on the most important organizational parameters in the company. The usefulness should be reflected in the company's policy on the organization of processes and activities as well as the respective specifics of such policy.

The managers - respondents' assessments on the three levels of the scoring scale for the condition of the parameters of organization design of (in) the company have been summarized.

This substantial "step" of the analysis reveals the common view and position of the respondents on two important questions:

The first question - which facets of the company's organization design are "good practices" revealed through high-scored organizational parameters;

The second question - which facets of company's organization design are characterized as "problematic practices", identified through satisfactory and unsatisfactory general score for certain organizational parameters.

Expert study of the condition of organization design of the company.

This "step" is based on the above two "steps". An expert study requires an in-depth look into the reasons, factors and limitations giving rise to the "problematic areas" in the company's design, unsatisfactory scores for certain organizational parameters, respectively.

The expert study continues by focusing on revealing the impact such "problematic areas" of the company design have and exert on the ongoing processes (7-8-9) and activities, and in particular on the performance of company's human resources and its results. The expert study must further aim to reveal the impact created and exerted by the company's organizational level on its competitiveness. Undoubtedly, company's organization design (spatial; temporal; interacting processes, etc.) does influence company's competitiveness. This basic premise is scientific and valid but in this case it must find its specific representation through the expert study.

Systematization and justification of project decisions, measures, actions to increase company's organization design level.

This last "step" stems from the expert study; it is aimed at specific decisions to overcome "problematic areas" in the company's organization design"; it is related to investments in the implementation of the project decisions. Undoubtedly, not all "problematic organizational parameters" can be improved (optimized) simultaneously and in that regard this is a matter of priorities accommodated in consideration of various limitations.

Comparative analysis of company's organizational profiles.

The argument for the need to develop company's organizational profiles on a regular basis is illustrated through the possibilities for a comparative analysis of the profiles and the dynamics of their change over time. 
A second opportunity when employing the comparative analysis concerns the development, in the company, of differentiated organizational profiles. These are used (while taking certain limitations into account) to derive benefits also in terms of improving company's organization design, i.e. to transfer positive experience from one structural unit to another within the company.

The comparative analysis is especially helpful and necessary for the organizational profiles in big companies, including those employing the holding type structure due to the possibilities to compare and transfer experience between its constituent subsidiary companies, separate plants and production facilities, production workshops, etc.

The following can be identified as basic guidance for the comparative analysis of organizational profiles:

a) Analysis of dynamics (change) of a company's organizational profile or that of the selected structural unit.

The analysis reveals the extent to which the problematic organizational parameters from the preceding period have been overcome (by employing the respective management measures and actions; the emergence of new (limiting) parameters and the causes behind them.

b) Analysis of the relationship between the improvement of the company's organizational level and the results achieved.

This analysis provides guidance to management as to the efficiency of the measures and actions which have been undertaken and implemented in order to increase the level of company's organization design.

\section{CONCLUSION}

The approach and methodological issues concerning the development of company's organizational profile presented in the article are based on scientific premises regarding companies' organization and organization design. The novelty of the article is the proposed own (author's) specification of organizational parameters as well as a number of methodological steps of the expert study on their condition. The conduct of studies on the condition of companies' organization design based on the methodological issues discussed herein, allows for opportunities to narrow the scope of their policy with respect to pressing and necessary project decisions on the improvement of their organization design. At the same time, the content of the article provides arguments and confirms that organization of (in) a company is not a one-off act but a continuous process whose effects are seen in an improved organization of processes. Undoubtedly, the effects also have specific dimensions - related to increasing compliance with the basic principles of company organization; optimization of companies' production costs; ultimately, ensuring that company's products are competitive and companies' competitiveness is increasing.

\section{REFERENCES}

1. Iliev, Y. Sistemi za upravlenie na choveshkite resursi, Izd. Makros, Plovdiv, 2016;

2. Varamezov, L. Organizatsia na predpriyatieto, Izd. Feber, S, 2009;

3. Hadzhiev, Kr. Teoria na orgnizatsiayata, Izd. NBU, S, 2011;

4. Hadzhiev, Kr. Modeli na organizatsionno savarshentstvo, Izd. NBU, S, 2013;

5. Dzhonev, S., Dimitrov, Pl. Orgnizatsionno konsultirane, Menidzhmant, Upravlenie na choveshkite resursi, 2015;

6. Popov, G, Y. Marinova Ikonomika i organizatsia na fermata, Izd. Goreks Pres, 2006;

7. Slavova, P. Modelirane na biznes protsesite chrez sashtestvuvashti softuerni in instrumenti, Jubilee, $X$ International Scientific Conference - „Management and Engineering"12 Sozopol, Bulgaria, Vol.1.,2012;

8. Slavova, P. Upravlenie na protsesi na dinamichna biznes sreda, International Scientific Conference „Management of change" Stara Zagora, 2013]

9. Slavova, P. Strategic decisions in business process management in industrial enterprises, XIII International Scientific Conference - ,Management and Engineering"12 Sozopol, Bulgaria, Vol.1.,2015; 